\title{
PENGARUH PENGGUNAAN TEPUNG DAUN DAN BATANG UBI JALAR (VINES) DALAM RANSUM TERHADAP KECERNAAN LEMAK DAN SERAT KASAR PADA TERNAK BABI
}

\author{
Maikel Yigibalom, C. A. Rahasia*, Ch. J. Pontoh \\ Fakultas Peternakan Universitas Sam Ratulangi, Manado 95115
}

\begin{abstract}
ABSTRAK
Ternak babi merupakan salah satu komoditas yang memiliki potensi besar untuk dikembangkan karena memiliki sifatsifat menguntungkan yaitu kesanggupan ternak babi dalam mengubah bahan makanan lebih efisien. Suatu penelitian telah dilaksanakan untuk mengetahui pengaruh penggunaan tepung daun dan batang ubi jalar (vines) dalam ransum terhadap kecernaan lemak dan serat kasar pada ternak babi. Penelitian ini dilaksanakan selama 50 hari, sejak tanggal 20 Juni sampai dengan 09 Agustus 2017, menggunakan 5 (lima) ekor babi jantan kastrasi hasil persilangan Duroc X Spotted Poland China berumur sekitar 3,5-4.0 bulan, berat badan awal $30 \mathrm{~kg}$ : Ransum perlakuan sebagai berikut: R0 $=100 \%$ Ransum Dasar $+0 \%$ Tepung Daun dan Batang Ubi Jalar, R1 $=92,5 \%$ Ransum Dasar $+7,5 \%$ Tepung Daun dan Batang Ubi Jalar, R2 $=85 \%$ Ransum Dasar $+15 \%$ Tepung Daun dan Batang Ubi Jalar, R3 = 77,5\% Ransum Dasar + 22,5\% Tepung Daun dan Batang Ubi Jalar. Dan R4 $=70 \%$ Ransum Dasar $+30 \%$ Tepung Daun dan Batang Ubi Jalar. Parameter yang diamati yaitu kecernaan lemak dan serat kasar. Hasil penelitian menunjukkan penggunaan Tepung daun dan batang ubi jalar memberikan pengaruh tidak berbeda nyata $(\mathrm{P}>0.05)$ terhadap nilai kecernaan serat kasar dan lemak. Penggunaan
\end{abstract}

*Korespondensi (corresponding author): Email: camelia_rahasia@yahoo.com
Tepung daun dan batang ubi jalar memberikan pengaruh yang berbeda nyata $(\mathrm{P}<0.05)$ terhadap nilai kecernaan serat kasar dan lemak atau minimal salah satu pasang yang berbeda. Dapat disimpulkan bahwa tepung daun dan batang ubi jalar (vines) dapat digunakan sampai dengan $30 \%$ dalam ransum ternak babi jantan kastrasi tanpa efek negatif terhadap kecernaan lemak dan serat kasar ransum.

Kata kunci: Tepung daun dan batang ubi jalar, kecernaan,, ternak babi.

\section{ABSTRACT}

THE EFFECT OF USING SWEET POTATO LEAVES (VINES) IN RATIONS ON DIGESTIBILITY FAT AND CRUDE FIBER IN PIGS. Pig livestock is one of the commodities that has great potential to be developed because it has beneficial properties, namely the ability of pigs to convert food ingredients more efficiently. A study has been carried out to determine the effect of using sweet potato leaves (vines) in rations on digestibility fat and crude fiber in pigs. This research was conducted for 50 days, from June 20 to August 9, 2017. This study used 5 (five) castrated male pigs from crosses of Duroc $\mathrm{X}$ Spotted Poland China around 3.5-4.0 months old, $30 \mathrm{~kg}$ initial weight: The treatment ration formulated as follows: R0 $=100 \%$ Basic Ration $+0 \%$ Leaves and Stems of Sweet Potatoes R1 $=92.5 \%$ Basic Ration $+7.5 \%$ Sweet Potato Flour and Stems R2 $=85 \%$ Basic Ration $+15 \%$ Sweet 
Potato Leaf and Stem Flour R3 $=77.5 \%$ Basic Ration $+22.5 \%$ Leaf and Stem Flour Sweet Potato R4 $=70 \%$ Basic Ration + $30 \%$ Leaf Flour and Sweet Potato Flour. Parameters observed were fat and crude fiber digestibility. The use of sweet potato leaves and stems flour did not have significant effect $(\mathrm{P}>0.05)$ on the digestibility value of crude fiber and fat. The use of sweet potato leaves and stems gave significantly different effects (P $<0.05)$ on the digestibility value of crude fiber and fat or at least one different pair. It can be concluded that the leaves and stems of sweet potatoes (vines) can be used up to $30 \%$ in the ration of castrated male pigs. without negative effects on fat digestibility and crude fiber ration.

Keywords: sweet potato leaves, digestibility, pig

\section{PENDAHULUAN}

Tepung ikan dan tepung kedele selama ini masih merupakan sumber protein ransum yang dapat diandalkan. Konsekuensinya yaitu permintaan akan kedua bahan baku pakan tersebut terus mengalami peningkatan walaupun harganya mahal. Salah satu langkah yang harus diambil untuk memenuhi peningkatan permintaan bahan baku pakan konvensional yaitu mencari bahan-bahan pakan inkonvensional yang mudah didapat, murah harganya, dan tidak bersaing dengan kebutuhan manusia.

Salah satu bahan pakan yang tersedia dan masih dianggap sebagai limbah yaitu daun dan batang ubi jalar (Ipomoea batatas (L.) Lam.). Daun dan batang ubi jalar belum banyak dimanfaatkan khususnya dalam susunan ransum ternak babi. Daun dan batang ubi jalar (sweet potato foliage atau sweet potatoes vine) memiliki potensi yang sangat besar untuk dijadikan pakan. Sekitar $43 \%$ produksi tahunan ubi jalar di dunia digunakan sebagai pakan (International Potato Center, 1998).

Tanaman ubi jalar secara keseluruhan sangat baik untuk bahan pakan karena akarnya memproduksi umbi ubi jalar yang dapat digunakan sebagai sumber energi dan daun serta batangnya dapat dimanfaatkan sebagai sumber protein (Peters, 2004). Pemberian pakan umbi ubi jalar pada ternak babi dan ternak lainnya merupakan praktek yang umum ditemukan dibanyak Negara termasuk China, Vietnam Utara dan Tengah, beberapa kepulauan bagian timur Indonesia (Bali dan Papua), Filipina, Papua New Guinea, Cuba dan Uganda (Scott, 1991).

Daun dan batang ubi jalar dapat diberikan pada ternak dalam bentuk segar, kering atau silase dan dapat merupakan bahan pakan yang sangat disukai ternak (palatabel) dengan bau, rasa dan aroma yang enak (Lebot, 2009). Daun dan batang ubi jalar kering dikatakan dapat mengimbangi hay alfafa dalam hal 
palatabilitasnya pada ternak sapi. Daun dan batang ubi jalar dapat dikeringkan, digiling untuk dijadikan tepung atau dicampur dengan hasil ikutan pembuatan gula tebu (Duke, 1983). Komposisi kimia daun dan batang ubi jalar yaitu bahan kering $88.46 \%$, protein kasar $25.51 \%$, Abu $14.22 \%$, serat kasar $24.29 \%$, lemak $1.15 \%$, bahan ekstrak tanpa nitrogen (BETN) 34.70\%, dan kalsium (Ca) $0.79 \%$ (Laboratorium Ilmu dan Teknologi Pakan Fakultas Peternakan, IPB, 2008).

Selama ini daun dan batang ubi jalar yang masih dikategorikan sebagai limbah pertanian masih belum banyak dimanfaatkan untuk pakan, khususnya babi Penelitian ini dirancang untuk mengetahui sejauh mana pengaruh penggunaan tepung daun dan batang ubi jalar menggantikan sebagian ransum dasar berpengaruh terhadap kecernaan lemak dan serat kasar pada ternak babi.

\section{MATERI DAN METODE PENELITIAN}

Penelitian ini dilaksanakan selama 50 hari, menggunakan 5 (lima) ekor babi jantan kastrasi hasil persilangan Duroc X Spotted Poland China berumur

Tabel 1. Komposisi Zat-zat Makanan dan Digestible Energy Bahan Pakan Penyusum Ransum*)

\begin{tabular}{lccccccc}
\hline \multicolumn{1}{c}{ Bahan Pakan } & $\begin{array}{c}\text { Protein } \\
(\%)\end{array}$ & $\begin{array}{c}\text { Lemak } \\
(\%)\end{array}$ & $\begin{array}{c}\text { Serat } \\
\text { Kasar }\end{array}$ & Abu & Ca & P & $\begin{array}{c}\text { Digestible } \\
\text { Energy (DE) }\end{array}$ \\
& - -----------------------------\% & ------------------------- & (kkal/kg) \\
Jagung & 9,42 & 5,17 & 2,15 & 15,13 & 0,22 & 0,60 & 3,180 \\
Dedak & 13,44 & 6,07 & 6,35 & 10,33 & 0,19 & 0,73 & 2,873 \\
Bungkil Kelapa & 24,74 & 9,36 & 15,02 & 6,95 & 0,11 & 0.47 & 3,495 \\
Tepung Ikan & 55,59 & 12,10 & 0,017 & 20,10 & 5,10 & 2,08 & 3,699 \\
Tepung Kedele & 40,38 & 9,91 & 6,56 & & 0,24 & 0,58 & 2,708 \\
Minyak & & 100,00 & - & - & - & - & 9,395 \\
Mineral Mix & & & & & 5,38 & 1,44 & - \\
Daun Ubi Jalar & 16,72 & 3,16 & 25,81 & 13,19 & 1,09 & 0,62 & 3,581 \\
\hline
\end{tabular}

${ }^{*}$ Ket: Hasil Analisis Laboratorium Ilmu dan Teknologi Pakan Fakultas Peternakan, IPB (2017) 
Tabel 2. Komposisi Bahan Pakan dan Kandungan Zat-zat Makanan dan Digestible Energi Ransum Perlakuan*)

\begin{tabular}{|c|c|c|c|c|c|}
\hline Bahan Pakan & R0 & $\mathrm{R} 1$ & $\mathrm{R} 2$ & R3 & $\mathrm{R} 4$ \\
\hline Jagung & 60,0 & 60,0 & 60,0 & 60,0 & 60,0 \\
\hline Dedak & 19,0 & 19,0 & 19,0 & 19,0 & 19,0 \\
\hline Bungkil Kelapa & 3,0 & 3,0 & 3,0 & 3,0 & 3,0 \\
\hline Tepung Ikan & 10,0 & 10,0 & 10,0 & 10,0 & 10,0 \\
\hline Tepung Kedele & 7,0 & 7,0 & 7,0 & 7,0 & 7,0 \\
\hline Mineral Mix & 1,0 & 1,0 & 1,0 & 1,0 & 1,0 \\
\hline Total & 100 & 100 & 100 & 100 & 100 \\
\hline Ransum Dasar & 100 & 92,5 & 85 & 77,5 & 70 \\
\hline Tepung Daun dan Batang Ubi Jalar & 0 & 7,5 & 15 & 22,5 & 30 \\
\hline \multicolumn{6}{|l|}{ Kandungan Nutrien } \\
\hline Protein & 17,33 & 17,94 & 17,24 & 17,19 & 17,14 \\
\hline Lemak & 6,43 & 6,19 & 5,94 & 5,70 & 5,45 \\
\hline Serat Kasar & 3,40 & 5,08 & 6,76 & 8,44 & 10,12 \\
\hline $\mathrm{Ca}$ & 0,75 & 0,77 & 0,80 & 0,82 & 0,85 \\
\hline $\mathrm{P}$ & 0,57 & 0,66 & 0,65 & 0,64 & 0,62 \\
\hline $\mathrm{DE}(\mathrm{Kkal} / \mathrm{kg})$ & 3118,0 & 3152,0 & 3187,0 & 3222,0 & 3257,0 \\
\hline
\end{tabular}

${ }^{*}$ Ket: Dihitung berdasarkan hasil analisis pada Tabel 3

kastrasi hasil persilangan Duroc X Spotted Poland China berumur sekitar 3,5-4.0 bulan, berat badan awal $30 \mathrm{~kg}$. Kandang yang digunakan dalam penelitian ini yaitu kandang percobaan 5 unit dengan ukuran 150 x 125 x $100 \mathrm{~cm}$. Setiap kandang dilengkapi dengan tempat makan dan minum. Lantai kandang terbuat dari beton dan antar unit dibatasi sekat kayu atau bambu. Peralatan yang digunakan yaitu timbangan standar $20 \mathrm{~kg}$, timbangan Ohaus 2600 gr. Bahan pakan penyusun ransum terdiri dari jagung kuning, dedak halus, tepung ikan, tepung kedelai, bungkil kelapa, dan mineral mix. Daun dan batang ubi jalar dipotong-potong dan dikeringkan kemudian dibuat tepung / mass. Komposisi zat zat makanan dan digestible energy (DE) bahan pakan penyusun ransum tercantum pada Tabel 2.

Penelitian ini menggunakan rancangan bujur sangkar latin (Latin Square Design) sesuai petunjuk (Steel and Torrie, 1991) yang terdiri dari 5 periode dan 
5 ekor ternak. Sebagai perlakuan adalah tepung daun dan batang ubi jalar menggantikan sebagian ransum ternak babi.

Ransum perlakuan yang diformulasi sebagai berikut:

$\mathrm{R} 0=100 \%$ ransum dasar $+0 \%$ tepung daun dan batang ubi jalar

$\mathrm{R} 1=92,5 \%$ ransum dasar $+7,5 \%$ tepung daun dan batang ubi jalar

$\mathrm{R} 2=85 \%$ ransum dasar $+15 \%$ tepung daun dan batang ubi jalar

$\mathrm{R} 3=77,5 \%$ ransum dasar $+22,5 \%$ tepung daun dan batang ubi jalar

$\mathrm{R} 4=70 \%$ ransum dasar $+30 \%$ tepung daun dan batang ubi jalar

\section{Variabel yang Diamati}

Untuk melihat pengaruh penggantian sebagian ransum dengan tepung daun dan batang jalar pada ternak babi. variabel yang akan diukur yaitu sebagai berikut:

1. Koefisien cerna lemak ransum (KCL) dihitung berdasarkan rumus yang dikemukakan oleh Banerjee (1978) sebagai berikut:

$\mathrm{KCL}=\frac{(\text { Kons R x \% LR })-\left(\sum \text { Fes x\% L Fes }\right)}{(\text { Kons R x\% LR })} \mathrm{X} 100$

Ket:.

$\mathrm{KCL}=$ koefisien cerna lemal ransum $(\%)$ Kons $\mathrm{R}=$ jumlah ransum yang dikonsumsi $\left(\right.$ kg.ekor $^{-1} \cdot$ hari $^{-1}$ )
LR = lemak ransum (\%)

$\sum$ Fes $=$ jumlah feses yang didefikasi $\left(\right.$ kg.ekor $^{-1} \cdot$ hari $\left.^{-1}\right)$

$\%$ Lfes $=$ kandungan lemak feses $(\%)$

2. Koefisien cerna serat kasar ransum (KCSK) dihitung sebagai berikut:

KCSK

$\frac{(\text { Kons.R x \% SK R })-\left(\sum \text { Fes x \% SK Fes }\right)}{(\text { Kons R x \% SK R })}$ X 100

Ket:

KCSK = Koefisien cerna serat kasar ransum (\%)

Kons $\mathrm{R}=$ Jumlah ransum yang dikonsumsi (kg.ekor ${ }^{-1}$.hari $\left.{ }^{-1}\right)$

SK R = serat kasar ransum (\%)

$\sum$ Feses $=$ jumlah feses yang didefikasi $\left(\right.$ kg.ekor $^{-1} \cdot$ hari $^{-1}$ )

$\%$ SK fes $=$ serat kasar feses $(\%)$

\section{Tatalaksana Penelitian}

Pada masa pendahuluan (selama 10 hari) semua ternak percobaan diberi obat cacing dilanjutkan pemberian obat diare. Air minum diberikan ad libitum. Pemberian ransum percobaan dan ransum kontrol juga diberikan ad libitum selama 7 hari pertama, pada hari ke 8 hitung rata-rata konsumsi perekor, kemudian hari ke 8-10 diberikan ransum $80 \%$ dari rata-rata konsumsi selama 7 hari pertama dan diberikan sedikit demi sedikit agar tidak terbuang. Makanan diberikan setiap hari dimulai dari jam 07.00 pagi sesudah kandang dan ternak dibersihkan. Hari ke $8-10$ berikan ransum $80 \%$ dari rata-rata konsumsi selama 7 hari pertama. Semua ternak yang digunakan dalam penelitian ini masing-masing memperoleh kelima perlakuan dalam 5 (lima) periode percobaan sesuai dengan bagan acak yang dilakukan. 


\section{HASIL DAN PEMBAHASAN}

Rataan angka kecernaan lemak dan serat kasar ransum selama penelitian disajikan pada Tabel 3.

\section{Pengaruh Perlakuan Terhadap Kecernaan Lemak.}

Rataan angka kecernaan lemak dalam penelitian ini dapat dilihat pada Tabel 3. Pada Tabel tersebut, terlihat rataannya berkisar antara 70,70-72,31\% dimana angka kecernaan lemak tertinggi ada pada perlakuan R2 (substitusi 15\% daun dan batang ubi jalar dengan ransum dasar) dan terendah R1 (substitusi 7,5\% daun dan batang ubi jalar dengan ransum dasar). Hasil analisis keragaman menunjukkan bahwa perlakuan penggunaan daun dan batang ubi jalar sebagai pengganti sebagian ransum dasar memberikan pengaruh tidak berbeda nyata $(\mathrm{P}>0,05)$ terhadap kecernaan lemak. Hal ini mengindikasikan bahwa masing-masing perlakuan memberikan respon yang sama terhadap kecernaan lemak meskipun kandungan lemak ransum semakin menurun dengan meningkatnya tepung daun dan batang ubi jalar tidak mempengaruhi angka kecernaan lemak itu sendiri.

\section{Pengaruh Perlakuan Terhadap Kecernaan Serat Kasar.}

Rataan angka kecernaan serat kasar dalam penelitian ini dapat dilihat pada Tabel 3. Pada Tabel tersebut, terlihat rataannya berkisar antara 60,76-61,95\% dimana angka kecernaan serat kasar tertinggi ada pada perlakuan R3 (substitusi $22,5 \%$ daun dan batang ubi jalar dengan ransum dasar) dan terrendah R1 (substitusi 7,5\% daun dan batang ubi jalar dengan ransum dasar). Hasil analisis keragaman menunjukkan bahwa perlakuan penggunaan daun dan batang ubi jalar sebagai pengganti sebagian ransum dasar

Tabel 3. Rataan Angka Kecernaan Lemak dan Serat Kasar Ransum Selama Penelitian

\begin{tabular}{lccccc}
\hline \multirow{2}{*}{ Kecernaan } & \multicolumn{5}{c}{ Perlakuan } \\
\cline { 2 - 6 } & R0 & R1 & R2 & R3 & R4 \\
\hline Lemak (\%) & 71,58 & 70,70 & 72,31 & 70,73 & 70,82 \\
Serat kasar (\%) & 61,64 & 60,76 & 61,16 & 61,95 & 61,23 \\
\hline
\end{tabular}


memberikan pengaruh berbeda tidak nyata $(\mathrm{P}>0,05)$ terhadap kecernaan serat kasar. Hal ini mengindikasikan bahwa masingmasing perlakuan memberikan respons yang sama terhadap kecernaan serat kasar ransum penelitian ini.

Montagne et al. (2003) menyatakan bahwa adanya peningkatan kandungan serat kasar dalam ransum akan mengakibatkan kecukupan zat-zat makanan seperti protein dan lemak menjadi kritis. Len et al. (2009) juga menyatakan bahwa tingginya kandungan serat kasar ransum akan menurunkan tingkat pertumbuhan dan kecernaan nutrien oleh adanya perubahan dalam gerak laju digesta atau transit time dalam saluran alat pencernaan. Lindberg (2014) menyimpulkan bahwa terdapat hubungan timbal balik antara serat kasar ransum dengan angka koefisien cerna nutrien. Semakin tinggi level serat kasar ransum, semakin rendah angka koefisien cerna nutrien. NRC (1988) menyatakan bahwa jika ransum mengandung serat kasar berlebih $(>5-7 \%)$ tanpa disertai adanya kenaikan kandungan lemak ransum, tingkat pertambahan berat badan dan efisiensinya akan menurun.

Hedemann et al. (2006) menjelaskan bahwa persentase serat kasar dalam ransum (crude fiber) tidak sama dengan serat yang masih mengandung nutrisi (total dietary fiber). Serat merupakan campuran kompleks dari konstituen-konstituen yang kurang dipahami. Dietary fiber merupakan rangka sel-sel tanaman yang tersisa dan tahan terhadap pencernaan. Walaupun utamanya adalah dinding-dinding sel tanaman yang mengandung selulosa, lignin, dan hemiselulosa di dalam dietary fiber tetapi juga terdapat polisakarida-polisakarida yang larut seperti pektin, getah-getah tanaman (plant gums), dan musilase (mucilages) (Neufeld, 2011). Serat (fiber) tidak semuanya adalah karbohidrat karena di dalamnya masih ada lignin, yang merupakan polimer bukan karbohidrat (non-carbohydratepolymer). Sebagai tambahan, fiber tidak semuanya berguna bagi ternak yang mengkonsumsinya; sedangkan sebagian dari dietary fiber dimetabolis dan dikonversi menjadi asamasam lemak terbang (volatile fatty acids) di saluran alat pencernaan (Ngoc et al., 2012; Ngoc et al., 2013).

Selama ini fiber dikenal dengan reputasi buruknya seperti menurunkan kecernaan nutrien, menurunkan densitas nutrien ransum dan menurunkan performans pertumbuhan ternak. Tetapi ini tidak berlaku bagi semua atau tidak benar bagi semua sumber serat (Mc Donald et al., 1999). Penjelasan ini diduga dapat menjawab kenapa tingginya level serat kasar ransum, terutama pada perlakuan R4 (substitusi ransum dasar dengan tepung daun dan batang ubi jalar sampai dengan 
$30 \%$ ) belum mempengaruhi kecernaan lemak dan serat kasar. Diduga bahwa komponen serat yang ada dalam tepung daun dan batang ubi jalar (vines) dikategorikan sebagai dietary fiber yang dan bukan crude fiber. Dapat dikatakan bahwa ternyata ternak babi dalam penelitian ini masih mampu mentolerir tingginya kandungan serat yang ada pada ransum perlakuan $\mathrm{R} 4$, dimana $30 \%$ proporsinya adalah daun dan batang ubi jalar (vines). Ini juga terindikasi dari hasil pengujian kecernaan dimana belum adanya efek negatif terhadap kecernaan lemak dan serat kasar yang ditunjukkan oleh ternak babi. Namun demikian, hasil penelitian ini masih perlu dibuktikan lebih lanjut lewat penelitian terhadap komponen serat yang terdapat dalam daun dan batang ubi jalar (vines) pada ternak babi.

\section{KESIMPULAN}

Dapat disimpulkan bahwa tepung daun dan batang ubi jalar (vines) dapat digunakan sampai dengan $30 \%$ dalam ransum ternak babi jantan kastrasi tanpa efek negatif terhadap kecernaan lemak dan serat kasar ransum.

\section{DAFTAR PUSTAKA}

Banerjee, G. C. 1978. Animal Nutrtion, Oxford LBH Publhising Co. Calcutta. Bombay. New Delhi.

Duke, J. A., 1983. Handbook of Energy Crops. New CROPS web site, Purdue University.

Hedemann, M.S., M. Eskildsen, H.N.Lærke, C. Pedersen, J.E. Lindberg, P. Laurinen, K.E. Bach Knudsen. $2006 . \quad$ Intestinal morphology and enzymatic activity in newly weaned pigs fed contrasting fibre concentrations and fibre properties. J Anim Sci. 2006, 84: 1375-1386.

International Potato Center 1998.Sweet Potato Facts.A Compendium of Key Figures and Analysis for 33 Important Sweet potato-producing Countries.Lima Peru.International Potato Center. IPB.Edisi Pertama. Bogor. Jakarta.

Lebot, V., 2009. Tropical root and tuber crops: cassava, sweet potato, yams and aroids. Crop production science in horticulture (17), CAB books, CABI, Wallingford, UK.

Len, N.T., T.T.T. Hong, J.E. Lindberg, B. Ogle. 2009. Comparison of total tract digestibility, development of visceral organs and digestive tract of Mong Cai and Yorkshire $\mathrm{x}$ Landrace piglets fed diets with different fibre sources. J Anim Physiol Anim Nutr. 2009, 93: 181191.View Article

Lindberg, J. E. 2014. Fiber Effects In Nutrition And Gut Health In Pigs. Journal OfAnimal Science And Biotechnology 5 (1):15

McDonald, D.E., D.W. Pethick, J.R. Pluske, D.J. Hampson. 1999. Adverse effects of soluble non-starch polysaccharide (guar gum) on piglet growth and experimental 
colibacillosis immediately after weaning. Res Vet Sci. 67: 245-250.

Montagne, L., J.R. Pluske, D.J. Hampson. 2003. A review of interactions between dietary fibre and the intestinal mucosa, and their consequences on digestive health in young non-ruminant animals. Anim Feed Sci Technol. 108: 95-117.View Article.

Neufeld, K. 2011. Eubiotic fibre in profitable pig production: The missing nutrient. Animal Nutrition Research Centre, Austria. Proc. The Agromed sponsored symposium 8 May, in conjunction with the 2011 Pig Feed Quality Conference in Cebu, the Philippines.

Ngoc, T.T.B., N.T. Len, J.E. Lindberg. 2013. Impact of fibre intake and fibre source on digestibility, gastrointestinal tract development, mean retention time and growth performance in indigenous (Mong Cai) and exotic (Landrace $\mathrm{x}$ Yorkshire) pigs. Animal. 7 (5): 736745.

Ngoc, T.T.B., T.T.T. Hong, N.T. Len, J.E. Lindberg. 2012. Effect of fibre level and fibre source on gut morphology and micro-environment in local (Mong Cai) and exotic (Landrace $\mathrm{x}$ Yorkshire) pigs. Asian-Austr J Animal Sci. 25 (12): 1726-1733.

Peters, D. 2004. Use of sweet potato in pig production in Asia:agricultural and socio-economic aspects. International Centre for Tropical Agriculture (CIAT)1, CIAT-Hanoi, 36 A/48 Tay Ho, Tay Ho District,Hanoi, Vietnam. Pig News and Information 25 (1), $25 \mathrm{~N}-$ 34N.@CAB International 2004.
Scott, G. J. 1991. Sweet potato as animal feed in developing countries: present patterns and future perspectives. Paper presented at the FAO Experts Consultation on "The Use of Roots, Tubers, Plantains and Bananas in Animal Feeding" held at the Centro International de Agricultura Tropical (CIAT), Cali, Colombia, 21-25 January 1991.

Steel, R.G.D. and J.H. Torrie. 1991. Prinsip dan Prosedur Statistik. Gramedia Pustaka Utama. Jakarta. 